\title{
CHEMICAL CONTROL OF WEEDS IN THE ATLANTIC PROVINCES
}

RESEARCH BRANCH-

CANADA DEPARTMENT OF AGRICULTURE

630.4

C212

P 1124

1961

c. 3

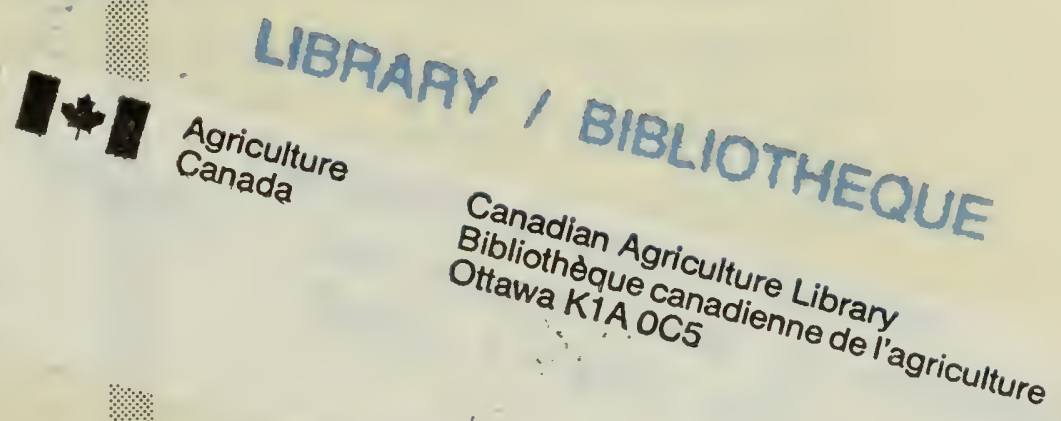

PUBLICATION $1 / 24$ JUNE 1961 
$\begin{array}{ll}\text { PAgE } & \end{array}$

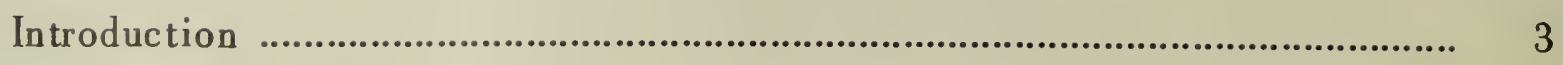

Regulations for Herbicides ...................................................................... 4

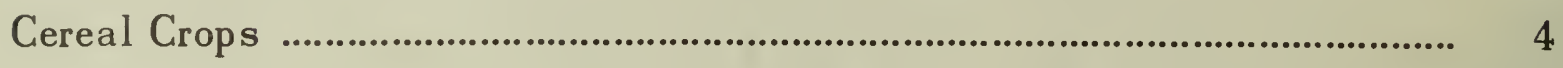

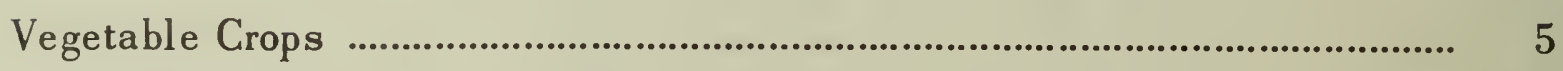

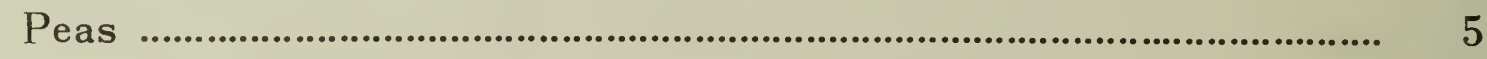

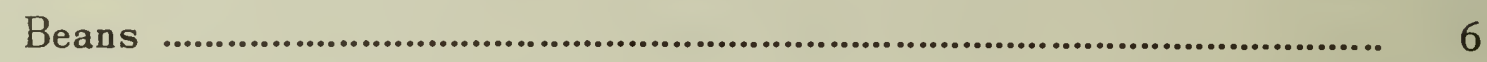

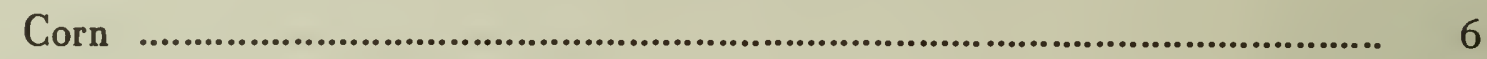

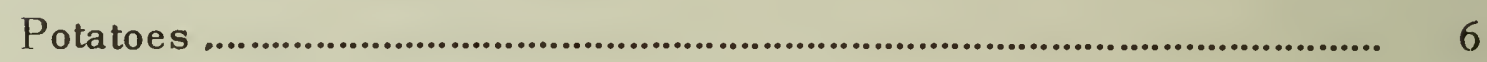

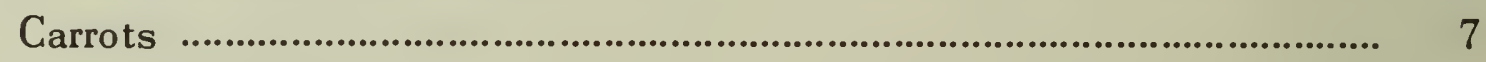

Parsnips, Parsley and Dill ................................................................. 7

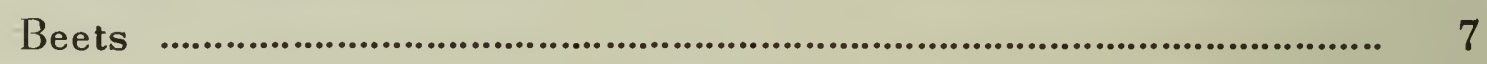

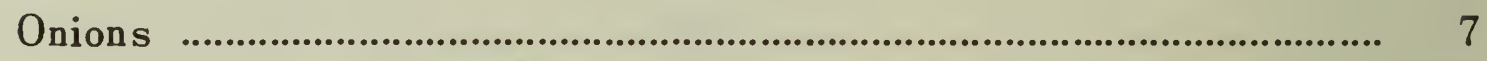

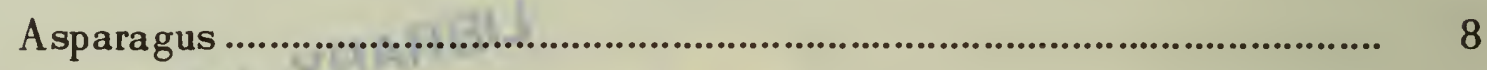

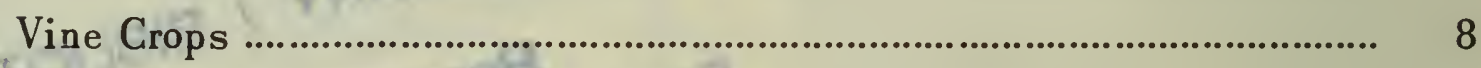

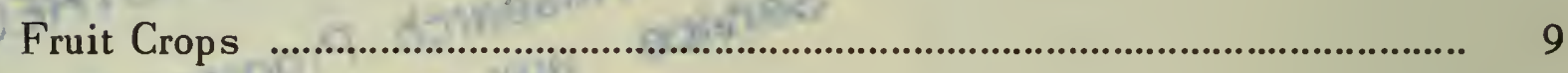

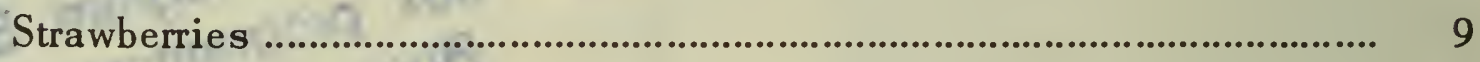

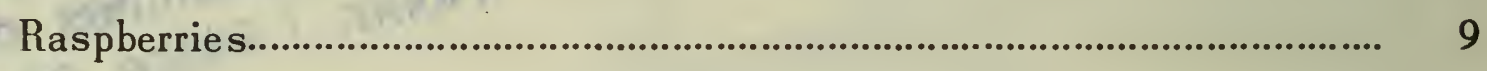

Lowbush Blueberries ....................................................................... 10

Fruit Trees .................................................................................. 10

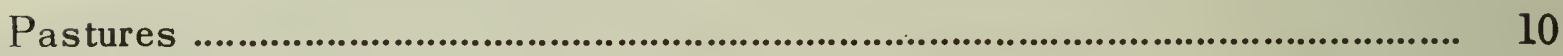

Couch or Quack Grass ...................................................................... 11

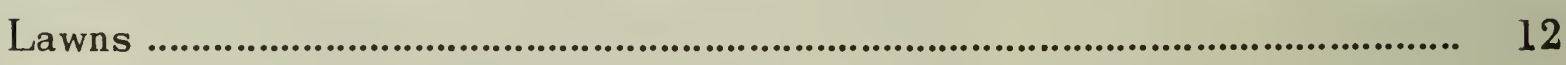

Weeds and Brush in Noncrop Land ....................................................... 12

Control of Woody Growth ......................................................................... 12

Sterilizing the Soil .......................................................................... 12

Some Common Weeds of the Atlantic Provinces ............................................ 13

Some Common Shrubs and Trees of the Atlantic Provinces and

Their Herbicidal Treatments 


\title{
CHEMICAL CONTROL OF WEEDS IN THE ATLANTIC PROVINCES
}

\author{
J.S. Leefe \\ Research Station, Kentville, Nova Scotia
}

\section{INTRODUCTION}

The control of weeds by herbicides is a rather recent development. The time and cost of weeding may often by reduced by use of a chemical, but control by chemicals will probably never entirely replace cultural methods. This publication provides a guide to the techniques of chemical weeding. The methods are based as far as possible on experience at research stations and experimental farms in the Atlantic Provinces of Canada.

Weeds, like cultivated crops, are plants, and the chemical used to kill them must not kill the cultivated plant as well. The tolerance of a crop plant to a herbicide may depend on a number of things. There are certain chemicals to which a crop may be entirely resistant but to which a number of common weeds may be very susceptible. This is an ideal situation and is not usual. More often the crop is only tolerant at a certain stage of growth. Something in the nature of the plant may make it tolerant, or it may have some physical character such as leaves or stems that shed water at a particular stage in its growth. Whatever the reason, if chemical control is to be successful, the appropriate herbicide must be applied in the right quantity at the proper time. Directions must be followed carefully and modified only after considerable experience.

Sprays and dusts are applied to the weeds or to the soil. Granular formulations, in which the chemical is carried on a clay granule, are applied only to the soil. Granules have some advantages over sprays. Water is unnecessary, and they do not adhere readily to dry plants. Consequently, it is often possible to apply granules over growing crops. Granules, however, must be used in rather small amounts and applied evenly over large areas.

Herbicides are usually classified according to time of application. There are three types.

(a) Pre-emergence applications. The herbicide is applied before the crop plants are up. Germinating weed seeds or emerged weeds, or both, may be destroyed. A smooth, firm soil surface is generally essential for success with this method.

(b) Postemergence applications. The herbicide is applied after the crop plants emerge. The effect of the herbicide depends on the chemical used, the stage of growth of the crop or the weeds, or a combination of all three. 
(c) Preplanting applications. The herbicide is applied to the soil before the crop is planted and may or may not be worked into the soil by tillage.

Most herbicides are applied as sprays. Use the correct amount of the active ingredient per acre and the right amount of water or other carrier. With sprays, the rate depends on use of the right nozzles, pressure and speed of travel. With granules the equipment must be carefully calibrated and adjusted so that only the necessary amount is applied.

Chemical weeding is no cure-all, but it is a useful supplement to good cultural practice. Often a combination of cultural and chemical techniques is better than either one alone.

\section{REGULATIONS FOR HERBICIDES}

Many chemicals are available for use as weed killers. Before a herbicide can be marketed in Canada it must be registered by the Plant Products Division of the Canada Department of Agriculture. For registration the recommendations and claims on the proposed label must be approved. The large number of chemicals and brands makes it hard to give general recommendations.

Labels of products that contain 2,4-D, MCPA, MCPB, 2,4-DB, 2,4,5-T, CMPP or 2,4,5-TP (silvex) specify the number of ounces by weight of acid equivalent in a gallon of liquid, or the percentage by weight of acid in dusts or granules. For other products, the labels must specify the content of active ingredient. Generally the recommendations in this publication are given as the quantity of acid equivalent or of active ingredient (whichever is applicable) required per acre or other specified area. For a few chemicals, when only one product is available, the recommendation is given in quantity of product required.

Products containing the same active ingredient are often formulated in different ways. The formulation may govern both effectiveness and hazard. For example, products containing 2,4-D are formulated as sodium salts, amines or esters; some of the esters give off the herbicide as vapor and this form presents a greater hazard than nonvolatile forms. On the other hand, esters are not readily washed off by rain falling before the herbicide has dried on treated vegetation. They are also somewhat more effective on weeds that are hard to kill.

Herbicides are potent materials, and careless use can lead to serious losses of crops and other valuable plants. Users should be sure that they understand the recommendations and hazards before applying any new or unfamiliar product.

\section{CEREAL CROPS}

In the Atlantic Provinces, cereals are usually undersown with grass or a mixture of grass and legumes. Herbicides that do not damage the cereal may cause severe injury to clovers. However, with correct timing and rate of application many of the common annual weeds such as lamb's-quarters, pigweed, wild radish, wild mustard and ragweed can be controlled with sprays of 2,4-D. 
Use the amine of 2,4-D at 6 ounces of acid equivalent per acre. Do not spray until a canopy of cereal plants and weeds covers the clover. With this limitation in mind, the earlier the spray is applied the more effective it is likely to be. This treatment does not control weeds that have come into bloom. MCPA, amine or sodium salt, can be used at somewhat higher rates (up to 8 ounces) but is no more effective except against a few weeds. These include corn spurrey, hemp nettle and horsetail.

MCPB and 2,4-DB can be used safely on clovers and 2,4-DB on alfalfa at rates up to 20 ounces of acid equivalent per acre. However, except for certain susceptible weeds they are not more effective than 2,4-D or MCPA used at rates that are safe on undersown cereals.

Cereals that are not undersown with legumes can be treated with 2,4-D at 8 ounces and MCPA at 12 ounces of acid equivalent per acre. Higher rates usually cause some injury to cereals although the loss may be justified in order to kill resistant weeds. When corn spurrey is the principal weed present, CMPP at 24 ounces of acid equivalent per acre gives the most effective control.

The amount of water in the mixture may vary greatly. With 2,4-D and MCPA it may be as little as 5 gallons per acre but with MCPB, 2,4-DB and CMPP it should not be less than 20 gallons.

\section{VEGETABLE CROPS}

Herbicides are useful in weeding a number of vegetable crops, but success with most of the methods depends on the quality of associated cultural practices. The fields need to be as free of weeds as possible and the seedbeds well prepared.

Most herbicides for weeding vegetable crops must be applied as pre-emergence treatments. The soil surface must be smooth and free of lumps. When spraying, use enough water in the mixture to completely cover the soil surface. This requires 35 to 40 gallons per acre.

For the control of broad-leaved weeds in large-seeded crops such as peas, beans, corn and potatoes, the standard herbicide is water-soluble dinitro (Premerge, Sinox PE, or equivalent). Before the crop is up, apply a spray containing 4 to 6 pounds (active ingredient) in 35 to 40 gallons of water per acre. This treatment gives freedom from broad-leaved weeds for 4 to 8 weeks, although it gives only fair to poor control of annual grasses such as barnyard grass. The weather may also make it impossible to apply the treatment in time.

\section{Peas}

Apply water-soluble dinitro 3 to 5 days before the peas are up, at 4 to 6 pounds (active ingredient) in 35 to 40 gallons of water per acre. Use the lower rate on sandy soils and the higher on heavy soils in cold, damp weather. 
Water-soluble dinitro also controls many broad-leaved weeds, including smartweed, after they emerge. Apply it at $1 \frac{1}{2}$ to 2 pounds in 35 to 40 gallons of water per acre when the peas are about 6 inches high. Put it on when weeds are small and when air temperatures are between $65^{\circ}$ and $75^{\circ} \mathrm{F}$. At higher temperatures it causes severe crop injury, and at lower temperatures it is not effective.

Peas can be sprayed with MCPB at rates as high as 2 pounds of acid equivalent per acre, although the number of weeds that can be killed with this treatment is rather limited. Sprays containing 1 pound of acid equivalent in not less than 20 gallons of water control Canada thistle and lamb's-quarters.

\section{Beans}

Water-soluble dinitro at 4 to 6 pounds (active ingredient) in 35 to 40 gallons of water per acre may be applied to beans up to the time they are in the crook stage.

\section{Corn}

Water-soluble dinitro, 4 to 6 pounds (active ingredient) in 35 to 40 gallons of water per acre, may be applied up to the time of emergence of field and sweet corn.

The most effective method for both types of corn is a spray containing 1 to 2 pounds (active ingredient) of simazine in 35 to 40 gallons of water applied before the weeds are up. Corn tolerates rates of simazine much higher than those required to control common annual weeds. However, use just enough to kill the weeds because simazine does not dissolve quickly and high rates may leave residues that may cause injury to crops sown after the corn. One pound per acre is satisfactory on sandy soils but 2 pounds are needed on soils high in organic matter or on heavy soils. Since the simazine remains near the surface of the soil, do not cultivate after spraying until you have to for the proper culture of the corn plants. Atrazine, a closely related chemical, but somewhat more soluble, gives better results in very dry weather and in areas of low rainfall, but under very wet conditions it may be lost by leaching before it is taken up by weed seedlings.

Corn can be treated with postemergence sprays of 2,4-D or MCPA at not more than 8 ounces of acid equivalent before the corn is 6 inches high. This is probably the most economical treatment against weeds that are susceptible to these herbicides.

\section{Potatoes}

Water-soluble dinitro, 4 to 6 pounds (active ingredient) in 35 to 40 gallons of water per acre, may be applied up to the time about 5 per cent of the potato sprouts have emerged.

Sprays containing 2,4-D or MCPA at 4 to 6 ounces of acid equivalent in 5 to 20 gallons of water per acre controls susceptible annual broad-leaved weeds. Apply the spray after the weeds emerge but before potato sprouts are showing. 
Dalapon, 4 pounds (active ingredient) per acre, may be added to the above applications to improve the control of annual grasses and couch grass ${ }^{1}$. Do not apply sprays containing dalapon after potato sprouts appear and do not use it on red-skinned varieties.

Cultivate lightly just before the sprouts appear, and apply the herbicide immediately. Further cultivation may improve weed control but will probably reduce potato yield.

\section{Carrots}

Susceptible annual weeds can be controlled in carrots with sprays of selective herbicidal oil. Use 60 to 80 gallons per acre for over-all spraying, and 30 to 40 gallons if the spray is banded over the rows. Spray when weeds are small, after the first true leaves have formed on the carrots and before the roots are $1 / 4$ inch thick. Some weeds, notably ragweed, are resistant.

A pre-emergence spray containing 6 pounds of CIPC (active ingredient) in 35 to 40 gallons of water controls most annual weeds, including annual grasses. Apply the spray within 1 to 2 days of seeding and when the soil surface is moist. Very heavy rain immediately after spraying reduces the effectiveness of this treatment.

\section{Parsnips, Parsley and Dill}

Use the oil treatment recommended for carrots. Parsnips must not be treated after the roots are $1 / 4$ inch thick.

\section{Beets}

There is no really effective herbicide for controlling broad-leaved weeds in beets, although the following treatments have sometimes given good results.

Endothal, 8 pounds (active ingredient) in 35 to 40 gallons of water per acre, may be applied as a pre-emergence spray or worked into the soil before planting. This treatment seems to give best results early in the season under cool, moist conditions. It is ineffective on organic soils.

Herbicidal oil applied before emergence at 80 gallons per acre (40 gallons if banded over the rows) helps to control lamb's-quarters.

TCA at 10 pounds (active ingredient) per acre in 35 to 40 gallons of water applied before emergence controls annual grasses. The treatment should be applied immediately after seeding.

\section{Onions}

Several chemical methods are available for weeding onions. None are entirely satisfactory although they reduce the time and cost of hand weeding.

A pre-emergence spray containing 4 pounds (active ingredient) of CIPC in 35 to 40 gallons of water per acre followed by one or two postemergence sprays

\footnotetext{
${ }^{1}$ See couch grass control, page 11 .
} 
containing 6 pounds of the same material gives good control of many annual weeds. The postemergence spray is not effective against lamb's-quarters, but is effective against chickweed and purslane.

Potassium cyanate, 6 to 8 pounds per acre when onions are small or 8 to 12 pounds on larger onions, is effective against many annual weeds. Apply the material in at least 50 gallons of water and do not use it until 2 or 3 weeks after the onions emerge. When the onions are large, direct the spray to the bases of the plants. This treatment is not effective against purslane.

Liquid cyanamide at 6 to 8 gallons per acre in 35 to 40 gallons of water controls many annual weeds in onions. Put it on after the onions are up and repeat the application as often a : necessary.

\section{Asparagus}

For control of annual weeds, before and after cutting, the best treatment is a spray containing 1 to 2 pounds of monuron in 35 to 40 gallons of water per acre. Use the lower rate on sandy soils. Apply the first treatment in the spring after disking and the second after the last cutting. Monuron is not safe to use in the season of planting.

Dalapon at 2 to 5 pounds (active ingredient) in 35 to 40 gallons of water after cutting is recommended for the control of seedling annual grasses.

For patches of hard-to-kill perennial weeds in well-established beds, amitrole at 8 pounds per 100 gallons of water is effective. It must be applied immediately after the last cutting and not at any other time.

Granular cyanamide, 300 to 400 pounds per acre, concentrated in an 18-inch band over the rows, kills many annual weeds in the seedling stage. This is an old procedure and success depends on the weeds being small and the weed foliage wet when the cyanamide is applied. The treatment may be applied before and after cutting. Calcium cyanamide is a source of fertilizer nitrogen.

\section{Vine Crops}

A pre-emergence spray containing 5 pounds of acid equivalent of NPA in 35 to 40 gallons of water per acre controls annual weeds in cucumber, squash, pumpkins and cantaloupe. The same treatment can be applied as a postemergence spray to cucumber and cantaloupe. Spray when the soil surface is moist and before weeds emerge. 


\section{FRUIT CROPS}

\section{Strawberries}

The control of weeds in strawberry beds presents a number of problems. With the matted-row system of culture that is followed in the Atlantic Provinces there are three stages in the development of strawberry beds, and each stage presents an entirely different problem in weed control. Strawberries cannot be grown successfully on land infested with weeds, so that a season spent cleaning up land before planting will probably pay dividends, particularly if couch grass or other hard-to-kill perennial weeds are present.

During the season of planting some cultivation will be necessary to keep runners in the rows and to keep the soil surface in a condition favorable to rooting of the runners. The herbicide SES helps to control many annual weeds and reduce the number of cultivations needed. Use 5 pounds per acre in 35 to 40 gallons of water. Because SES does not kill emerged weeds, but kills weed seeds as they germinate, the soil surface must be free of weeds when SES is applied. Make the first treatment 7 to 12 days after planting and after cleaning up all weeds. As the effect of SES does not last long, a second treatment may be necessary after a further cultivation and cleanup later in the season. SES should not be present in the soil when strawberry runners are rooting.

After runners have set, but before mulch is applied, winter-annual weeds will germinate, and unless controlled will grow under the mulch through the winter. At this time use a spray containing 2,4-D, at 8 ounces of acid equivalent in 20 gallons of water per acre. To avoid injury to the strawberries, do not apply 2,4-D later than the first week in September. A spray containing 3 pounds of CIPC in 35 to 40 gallons of water per acre, applied when strawberry plants are dormant, controls many annual weeds and is effective against chickweed. This treatment will cause severe injury to strawberry plants if they are not dormant, so do not use CIPC until after the first heavy fall frost.

Use clean straw for mulching. It is poor economy to spend a season keeping a strawberry bed free of weeds and then use a mulch that is full of weed seeds. Weed seeds carried in straw used for mulching germinate during the winter and spring and cause weedy strawberry beds during the picking season.

If strawberry beds are kept for a second crop year a spray of 2,4-D at 1 pound of acid equivalent per acre helps to control many broad-leaved weeds, both annual and perennial. This spray should be applied after berries have been picked and is most effective if delayed until weeds are growing vigorously, but not later than the first week in September.

\section{Raspberries}

Many broad-leaved weeds in raspberries can be controlled with 2,4-D, which can be used at rates up to $1 \frac{1 / 2}{2}$ pounds of acid equivalent per acre at any time 
except when raspberries are in bloom. Use the amine form. Direct the spray toward the bases of the canes, being careful to avoid the tips of young shoots.

Dalapon at 5 pounds (active ingredient) per 100 gallons of water is recommended for grass control. Apply it in the spring and direct the spray to the bases of the canes.

\section{Lowbush Blueberries}

To control lambkill, use 3 pounds of acid equivalent of 2,4-D ester in 50 gallons of water per acre. Apply it late in the fall of the year before you intend to burn, when most of the blueberry leaves have dropped but while the lambkill leaves are still green. Burn at any time from a month after spraying until the next spring.

To control sweet fern, use 2,4-D amine at 1 pound of acid equivalent in 50 gallons of water per acre. Apply it in early summer, especially if the sweet fern is thick enough to protect the blueberries. If the stand of fern is scattered and sparse, spray while the fern is still green but not until the blueberry leaves have changed color. The herbicide may also be applied with a power-operated, cloth-covered roller mounted behind a tractor. A solution containing 2 pounds of acid equivalent of 2,4-D amine in 100 gallons of water is dripped onto the roller, which wipes the sweet fern as it travels over the area. The roller is set higher than the blueberry plants.

Woody growth can be spot-treated by some of the methods given in the section "Control of Weeds and Brush in Noncrop Land," page 12.

\section{Fruit Trees}

To control broad-leaved weeds and grasses under newly planted, nonbearing apple, pear and peach trees, use a spray containing 5 pounds of amitrole in 100 gallons of water. Apply it in late spring when weed growth is vigorous. Be sure to use enough to wet the weeds thoroughly but without too much runoff. Do not apply the spray to bare ground under the trees. Do not apply it after a long period of dry weather, and keep it off the leaves of the trees.

To control grass under apple and pear trees, use a spray containing 10 pounds of dalapon in 100 gallons of water. Apply enough spray to wet the grass thoroughly and put it on when the grass is growing vigorously, preferably in the spring. However, do not apply it to bare ground under the trees, or to the leaves of trees; and do not use it after a spell of dry weather. Do not allow meat or dairy animals to graze on treated areas for 3 months after treatment.

\section{PASTURES}

Good management is essential to weed control in pastures even when herbicides are used. Many weeds such as the hawkweeds, ox-eye daisy, wild carrot and wild strawberry grow only on poor soils. Improvement of the soil with lime and fertilizer will help to bring this type of weed under control. 
Weeds such as Canada thistle, common dandelion and buttercup are found in fertile pastures. Mowing these weeds before seeds are formed will do much to prevent their spread.

To control most annual and biennial weeds in pastures, apply one or more sprays of 2,4-D or MCPA, 1 pound of acid equivalent per acre, in June and early September. White clover may be injured but it usually recovers. MCPA is less injurious to white clover but is less effective against many of the weeds.

Very high rates of MCPB can be used without injury to white clover. This herbicide at 3 pounds of acid equivalent per acre in not less than 20 gallons of water is effective against Canada thistle.

Ragwort (stinking Willie) and wild carrot cannot be controlled with less than 2 pounds of acid equivalent of 2,4-D per acre. Apply the spray to the rosettes in the spring and fall.

A spray containing 10 pounds (active ingredient) of dalapon or amitrol in 100 gallons of water is effective against cattails. Use enough spray to thoroughly wet all foliage. Both these materials kill grasses. Do not allow meat or dairy animals to graze on treated areas for 3 months after treatment.

Many of the methods given in the section "Control of Weeds and Brush in Noncrop Land," page 12, are applicable for the control of woody growth in pastures.

\section{COUCH OR QUACK GRASS}

It is hard to control couch grass under any circumstances, particularly in cultivated crops and under fruit trees. Because of the food reserves in the extensive roots, merely killing the tops does not eliminate the grass. Continuous tillage will eventually eradicate it, but this can be a time-consuming and expensive procedure. For speedy and efficient control it is better to combine herbicide treatment with tillage.

To eradicate couch grass in open fields, use a spray containing 10 pounds (active ingredient) of dalapon in 100 gallons of water, and wet all the grass to the point of runoff. Put it on when the grass is growing vigorously, preferably in the spring. Make the first cultivation 10 to 14 days after spraying and repeat it whenever new top growth appears. Fall treatment is less effective but usually is good enough to make possible the production of cultivated crops the following season. A year after fall spraying, a considerable recovery of couch grass may be expected. Fall spraying must be followed by plowing to completely bury all top growth.

Amitrol can be used in place of dalapon and this may be advantageous when it is necessary to control other weeds as well as couch grass.

Many crops can be planted 4 weeks after an area has had spring treatment with dalapon. The potato is very tolerant, and white-skinned varieties can be 
safely planted 4 days after treatment, although couch grass control will not be as effective as it would be if tillage and seedbed preparation were delayed 10 to 14 days after spraying.

For chemical control of grasses, including couch grass in fruit plantings, see page 10 .

\section{LAWNS}

Most broad-leaved weeds in lawns can be controlled with sprays containing 12 to 24 ounces of acid equivalent of $2,4-D$ per acre $(1 / 4$ to $1 / 2$ ounce per 1000 square feet). The chickweeds are resistant to 2,4-D but can be controlled with silvex or CMPP, at 24 ounces of acid equivalent per acre. These herbicides severely injure or kill white clover and none of them control crabgrass.

\section{WEEDS AND BRUSH IN NONCROP LAND}

Most of the methods described here were developed for nonagricultural purposes although many of the techniques have applications in agriculture.

\section{Control of Woody Growth}

The simplest and cheapest chemical method of controlling brush is by overall foliage spraying. For species that are susceptible, and when the unsightly dead top growth is not objectionable, this method should be used. Use enough liquid at a high enough pressure to thoroughly wet all the leaves. Brush or trees over 6 feet high should be cut and the regrowth sprayed when it develops. Use the 2,4-D ester or a mixture of 2,4-D and 2,4,5-T esters at 3 to 4 pounds of acid equivalent in 100 gallons of water, depending on the species present. ${ }^{2}$ Make sure that spray does not fall on susceptible crops or ornamental plants and that spray equipment is thoroughly cleaned before it is used for other purposes. Spray at a time of year when growth is vigorous, preferably early summer.

Most species, except conifers, that are resistant to over-all foliage sprays can be killed by basal treatment with a mixture of $2,4-\mathrm{D}$ and $2,4,5-\mathrm{T}$ in fuel oil. Use $1 \frac{1}{2}$ to 2 pounds of acid equivalent of each of $2,4-\mathrm{D}$ and $2,4,5-\mathrm{T}$ esters in 10 gallons of oil. Spray it on the lower 12 inches of the trunk and on all exposed roots of the growth that is to be killed. Treat freshly cut stumps with the same mixture to prevent regrowth. The entire stump, including exposed roots, must be treated. Basal and stump treatments are effective at any time of year.

Spruce, fir and pine can be killed with an over-all spray containing 25 pounds of TCA in 100 gallons of water. The treatment must be made during the growing season and very thorough coverage is needed.

\section{Sterilizing the Soil}

In some places such as roads, railway rights-of-way, waste places and hard tennis courts, you may need to kill all vegetation and maintain a sterile soil for as long a period as possible. There are a number of chemicals for this purpose

\footnotetext{
${ }^{2}$ See list of susceptible species, page 13.
} 
and the choice will depend on the job to be done, the cost and the length of time you want the effect to last.

Chemicals with a relatively long residual effect, because of low solubility, vary in effectiveness against deep-rooted vegetation. Because soil-sterilizing chemicals act through the root zone it may be necessary to remove the top growth of vegetation before applying the treatment to the soil.

Simazine or monuron at 20 to 40 pounds (active ingredient) per acre will give control for 1 or 2 years. Sandy soils generally need less material than heavy soils high in organic matter. Atrazine and diuron are similar to simazine and monuron but, being more soluble, give better penetration and shorter residual effect.

For control lasting one season only, mixtures of sodium chlorate and sodium borate are available. These should be used at 4 pounds per 100 square feet. Sodium chlorate is very soluble and will leach into the root zone and kill deeprooted plants. Addition of monuron to this mixture improves its residual effect. Mixtures of all three chemicals are also available.

When soil-sterilizing chemicals are used on roadways and other areas there is always a danger that the roots of plants growing nearby may extend to the treated area and consequently absorb enough chemical to be injured or killed. If the treated area is sloping, some of the chemical may 'wander' from the area of application, injuring or killing vegetation beyond the treated area.

\section{SOME COMMON WEEDS OF THE ATLANTIC PROVINCES}

The weeds in the following list are classified according to how readily they can be killed by 2,4-D. However, some of them are now known to be equally or more susceptible to other selective herbicides. Where this is the case it is indicated. The rates suggested do not take account of crop susceptibility, and for weeds in crops the recommendation for the particular crop must be followed.

A. Those that can be killed in the early, rapid stages of growth by sprays containing 4 to 8 ounces of acid equivalent of 2,4-D per acre.

Burdock

Common dandelion

Common plantain

Fall dandelion

Lamb's-quarters or common pigweed $(1,2)$

(1) Susceptible to MCPA.

(2) Susceptible to MCPB.
Quickweed

Redroot pigweed

Wild carrot (seedling stage only (1))

Wild mustard (1)

Wild radish or charlock (1) 
B. Those that can be killed by one or more sprays containing 8 to 16 ounces of acid equivalent of $2,4-D$ per acre.
Canada thistle $(1,2)$
Rough cinquefoil
Curled dock
Common chickweed (3)
Daisy
Goldenrod
Runaway robin or creeping Charlie
Sheep sorrel
Shepherd's-purse
Smartweed
Speedwell
Mouse-ear chickweed (3)
Orange hawkweed or devil's-paintbrush
Stinking Willie or ragwort
Tall buttercup (I)
Wild carrot (rosette stage)
Purslane
Yellow hawkweed or king devil (1)
Yellow rocket (1)

(1) Susceptible to MCPA.

(2) Susceptible to MCPB.

(3) Susceptible to CMPP and silvex.

C. Those that are resistant-control with 2,4-D not practical.

Annual grasses

Corn spurry $(1,2)$

Common St.-John's-wort

Couch grass

Goutweed
Hemp nettle (I)

Japanese knotweed

Black knapweed

Toadflax or butter-and-eggs

Yarrow

(1) Susceptible to MCPA at 8 to 12 ounces of acid equivalent per acre.

(2) Susceptible to CMPP at 24 ounces of acid equivalent per acre.

\section{SOME COMMON SHRUBS AND TREES OF THE ATLANTIC PROVINCES AND THEIR HERBICIDAL TREATMENTS}

A. Those that can be killed by 2 pounds of 2,4-D acid equivalent in 100 gallons of water per acre.
Alder
Elderberry
Birch
Honeysuckle
Blue berry
Wild cherry or pin cherry
Sumac
Chokecherry
Willow 
B. Those of which leaves and top growth can be killed by 2 pounds of 2,4-D acid equivalent in 100 gallons of water per acre. Two or more sprays on regrowth are required to kill the plant.
Aspen poplar
Hardhack
Balsam poplar
Poison ivy
Elm
Sweet ferm

(1) More readily killed with amitrole, at 3 pounds in 100 gallons per acre.

C. Those that cannot be killed with 2,4-D but can be killed by one or more applications of a mixture of 2,4-D and 2,4,5-T at a total of 3 to 4 pounds of 2,4-D and 2,4,5-T acid equivalent in 100 gallons of water per acre. (Commercial mixtures of 2,4-D and 2,4,5-Tare available and are sold as brush killers.)

Beech

Common black berry

Lambkill

Lilac

Maple

Oak

Rhodora

Wild raspberry

Wild rose

These species are more readily controlled by basal sprays of 2,4-D plus $2,4,5-\mathrm{T}$ in oil (see page 12 ).

D. Those that are very resistant to sprays of 2,4-D and mixtures of 2,4-D plus $2,4,5-\mathrm{T}$.

$\begin{array}{ll}\text { Spruce } & \text { Hemlock } \\ \text { Fir } & \text { Tamarack } \\ \text { Pine } & \end{array}$

See page 12 for control.

Some brand names are used in this publication because the chemical names are difficult forgeneral use and there are no official common names for the active ingredients. 
Copies of this publication may be obtained from:

Information Division

CANADA DEPARTMENT OF AGRICULTURE

Ottawa, Ontario

ROGER DUHAMEL, F.R.S.C.

QUEEN'S PRINTER AND CONTROLLER OF STATIONERY OTTAWA, 1961

Cat. No. A53-1124 